\title{
Risiko Fotoreaktivasi terhadap Kualitas Mikrobiologi Air Minum Isi Ulang
}

\author{
Prayudhy Yushananta ${ }^{1}$, Mei Ahyanti ${ }^{2}$ \\ Jurusan Kesehatan Lingkungan, Politeknik Kesehatan Tanjungkarang \\ Email: prayudhyyushananta@gmail.com
}

\begin{abstract}
Photoreactivation Risk on Microbiological Quality of Drinking Water Refills in Bandar Lampung City. Photoreactivation is a direct process of repairing a damaged DNA with the help of ultraviolet in the range of $320-370 \mathrm{~nm}$. Research is designed to acknowledge the effect of time exposure and UV vis ray's intensity to numbers of Coliforms and E.coli. The results prove the effect of UV exposure time on the increase of coliform which is $60,2 \%$ (p-value $=0,0001$ ). The increase of coliform happens after 180th minutes of exposure. But, in this research there is no effect of UV's intensity towards both numbers of coliform ( $p$-value $=0,152)$ and E.Coli ( $p$ value $=0,578$ ). Besides buying a refilled mineral water from a water depot whose disinfecting with UV ray and ozone combined, closing the gallon of mineral water since the first day being used to avoid being exposed by UV vis ray from the sun is a must-do to avoid photoreactivation process.
\end{abstract}

Keywords: Coliform, E.coli, Photoreactivation, UV vis

\begin{abstract}
Abstrak: Risiko Fotoreaktivasi terhadap Kualitas Mikrobiologi Air Minum Isi Ulang di Kota Bandar Lampung. Fotoreaktivasi merupakan proses perbaikan DNA yang rusak secara langsung dengan bantuan sinar ultraviolet dalam rentang 320-370 $\mathrm{nm}$. Penelitian dirancang untuk mengetahui pengaruh waktu pemaparan dan intensitas sinar UV vis terhadap jumlah Coliform dan E.coli. Hasil penelitian membuktikan adanya pengaruh waktu pemaparan sinar UV vis terhadap peningkatan jumlah Coliform yaitu sebesar 60,2\% ( $p$-value=0,0001). Peningkatan jumlah Coliform terjadi setelah menit ke-180 pemaparan. Namun, pada penelitian ini tidak terdapat pengaruh intensitas sinar UV vis terhadap jumlah Coliform $(p$-value $=0,152)$ maupun E.coli $(p$ value $=0,758)$. Selain membeli air minum isi ulang dari depot air minum yang melakukan proses desinfeksi dengan kombinasi sinar UV dan ozon, menutup galon air minum sejak pertama digunakan agar tidak terpapar sinar UV vis dari matahari merupakan upaya yang harus dilakukan untuk menghindari proses fotoreaktivasi.
\end{abstract}

Kata kunci: Coliform, E.coli, Fotoreaktivasi, UV vis

Hasil Riskesdas tahun 2013 mendapatkan bahwa proporsi rumah tangga di Indonesia yang memiliki akses terhadap sumber air minum sebesar $66,8 \%$, yaitu membeli air kemasan atau isi ulang $(30,7 \%)$, sumur gali terlindung $(22,5 \%)$, PDAM $(13,5 \%)$, sumur bor $(12,8 \%)$, mata air terlindung (7,6\%), penampungan air hujan $(2,9 \%)$, dan sumber air tidak sehat $(10 \%)$. Pada kelompok yang membeli air kemasan atau isi ulang, proporsi masing-masing sebesar 9,7\% dan $21 \%$. Data ini menunjukkan bahwa penggunaan air minum isi ulang merupakan proporsi terbesar setelah sumur gali terlindung.

Air minum isi ulang diproduksi di depot air minum. Depot air minum adalah badan usaha yang mengelola air minum untuk keperluan masyarakat dalam bentuk curah dan tidak dikemas (Kemenkes RI, 2010).

Proses pengolahan air minum yang dilakukan di depot air minum melalui dua tahap, yaitu penyaringan dan desinfeksi (Deperindag, 2004). Ada tiga metode yang sering digunakan pada proses desinfeksi air minum, yaitu metode sinar ultraviolet, ozonisasi dan reversed osmosis. Masing-masing metode memiliki kelebihan maupun kekurangan. Kelebihan metode ultraviolet adalah mudah, murah, tanpa residu dan mampu membunuh semua jenis mikroba (Suprihatin, 2003). Berdasarkan kelebihan itulah sebagian besar depot air minum menggunakan metode ultraviolet untuk proses desinfeksi

Hasil penelitian dibeberapa tempat menunjukkan hasil yang seragam, yaitu masih terdapat air minum dari depot air minum yang tidak memenuhi persyaratan kualitas mikrobilogi. Selain beberapa keuntungan yang didapat dengan menggunakan desinfeksi sinar UV juga terdapat beberapa kerugiannya yaitu: 1) Tidak ada residu disinfektan pada air yang telah diolah, sehingga diperlukan penambahan khlorin atau ozon setelah proses UV; 2) Pembentukan biofilm pada permukaan lampu; 3) Masalah dalam hal pemeliharaan dan pembersihan lampu UV; 4) Masih ada potensi terjadi fotoreaktivasi pada 
mikroba patogen yang telah diproses dengan UV (Said, 2007).

Fotoreaktivasi merupakan proses perbaikan DNA yang rusak secara langsung dengan suatu mekanisme pembalikan tunggal melibatkan suatu flavoprotein yang disebut fotoliase yang merubah dimer siklobutan kembali menjadi unsur pokoknya yaitu pirimidin. Peran fotoliase membutuhkan cahaya. Proses perbaikan dibantu oleh cahaya yang kelihatan dalam rentang 320-370 nm (Kusnadi, dkk, 2013).

Fotoreaktivasi dapat terjadi pada mikroba yang telah terpapar UV oleh gelombang cahaya tampak (visible) antara $300 \mathrm{~nm}$ dan $500 \mathrm{~nm}$. Segmen DNA yang rusak oleh UV akan hilang diganti dengan hasil sintesa segmen yang baru. Walaupun total dan fecal coliform mengalami fotoreaktivasi, namun fecal streptococci tidak mengalami. Oleh karena itu air yang telah diolah dengan UV tidak boleh terpapar oleh cahaya visible selama penyimpanan (Said, 2007).

\section{METODE}

Penelitian eksperimen ini menggunakan rancangan Pretest-Postest Control Group untuk mengetahui pengaruh waktu paparan dan intensitas sinar UV vis terhadap kualitas mikrobiologi air minum isi ulang. Variabel yang dikaji adalah kualitas mikrobiologi, intensitas UV vis, dan lama waktu pemaparan sinar UV vis.

Penelitian dilaksanakan di Laboratorium Jurusan Kesehatan Lingkungan pada bulan Juni Oktober 2016. Teknik analisis yang akan digunakan adalah $T$ Test, Anova dan Linier Regretion. Hasil analisis akan disajikan dalam bentuk frekuensi, tabel dan gambar.

\section{HASIL}

\section{Gambaran Hasil Penelitian}

Hasil penelitian mendapatkan bahwa rerata jumlah coliform sebelum perlakuan sebanyak $0,00 / 100 \mathrm{ml}$, sesudah perlakukan sebanyak 1,72/100 $\mathrm{ml}(\mathrm{SD}=3,64 / 100 \mathrm{ml})$. Jumlah E.coli sebelum perlakuan sebanyak $0,00 / 100 \mathrm{ml}$, sesudah perlakukan sebanyak $0,21 / 100 \mathrm{ml}$ $(\mathrm{SD}=1,36 / 100 \mathrm{ml})$.
Tabel 1. Jumlah Coliform dan E.coli Air Minum

\begin{tabular}{lcr}
\hline & \multicolumn{2}{c}{ Hasil Pengukuran $(. . / 100 m l)$} \\
\cline { 2 - 3 } & Coliform & E.coli \\
\hline Rerata & 1,72 & 0,21 \\
SD & 3,64 & 1,36 \\
Minimal & 0,00 & 0,00 \\
Maksimal & 15,00 & 9,00 \\
\hline
\end{tabular}

Waktu pemaparan ditentukan menjadi delapan, yaitu 15 menit, 30 menit, 60 menit, 120 menit, 180 menit, 240 menit, 300 menit, dan 360 menit.

Hasil penelitian mendapatkan bahwa rerata intensitas sinar UV vis sebesar $18,69 \mathrm{~mW}$ $(\mathrm{SD}=10,31 \mathrm{~mW})$. Hasil pengukuran intensitas sinar UV vis adalah sebagai

Tabel 2. Intensitas Sinar UV vis

\begin{tabular}{lr} 
& Hasil Pengukuran \\
\hline Rerata & $18,69 \mathrm{~mW} / \mathrm{cm} 2$ \\
SD & $10,31 \mathrm{~mW} / \mathrm{cm} 2$ \\
Minimal & $0,00 \mathrm{~mW} / \mathrm{cm} 2$ \\
Maksimal & $42,00 \mathrm{~mW} / \mathrm{cm} 2$ \\
\hline
\end{tabular}

\section{Pengaruh Waktu Paparan terhadap Kualitas Mikrobiologi Air Minum}

Pengaruh paparan sinar UV vis terhadap jumlah bakteri Coliform dan E.coli pada air minum dinilai menggunakan uji ANOVA.

Hasil analisis statistik menunjukkan adanya perbedaan rerata jumlah Coliform berdasarkan waktu pemaparan ( $p$-value $=0,0001)$. Dari hasil ini dapat disimpulkan bahwa adanya pengaruh waktu pemaparan sinar UV vis terhadap peningkatan jumlah bakteri Coliform.

Tabel 3. Pengaruh Waktu Pemaparan

\begin{tabular}{lrrr}
\multicolumn{1}{c}{ Coliform } & & & \\
\hline & df & F & Sig. \\
\hline Between Groups & 7 & & \\
Within Groups & 120 & 13,261 & 0,0001 \\
\hline Total & 127 & & \\
\hline
\end{tabular}

Perbedaan jumlah bakteri Coliform berdasarkan waktu pemaparan juga digambarkan pada gambar berikut. 


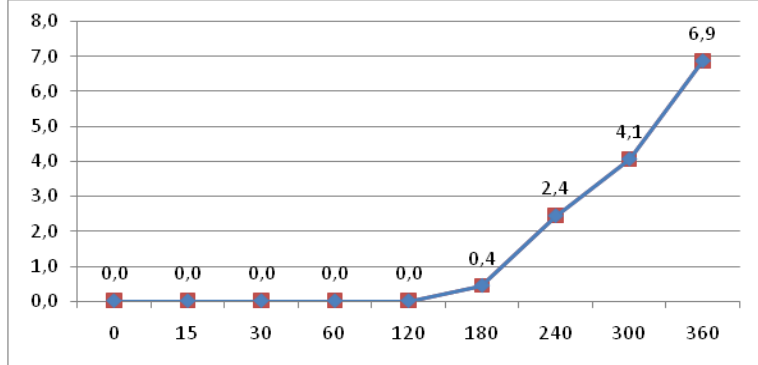

Gambar 1. Jumlah Coliform menurut Waktu Pemaparan (menit)

Gambar di atas menunjukkan bahwa rerata jumlah bakteri Coliform mulai meningkat setelah 180 menit pemaparan. Semakin lama waktu pemaparan, maka semakin tinggi jumlah Coliform pada air minum.

Pada penelitian ini juga dilakukan uji ANOVA untuk mengetahui waktu paparan sinar UV vis terhadap rerata jumlah bakteri E.coli. Hasil statistik menunjukkan tidak terdapatnya perbedaan rerata jumlah E.coli berdasarkan waktu $(p$-value $=0,159)$.

Tabel 4. Pengaruh Waktu Pemaparan E.coli

\begin{tabular}{|c|c|c|c|}
\hline & $f$ & $\mathrm{~F}$ & Sig. \\
\hline Between Groups & 7 & \multirow{3}{*}{1,545} & \multirow{3}{*}{0.15} \\
\hline Within Groups & 120 & & \\
\hline Total & 127 & & \\
\hline
\end{tabular}

Walaupun secara statistik, pengaruh waktu pemaparan sinar UV vis terhadap peningkatan jumlah bakteri E.coli tidak menunjukkan hasil signifikan, namun pada penelitian ini diketahui adanya pertumbuhan bakteri E.coli setelah menit ke-300 setelah pemaparan.

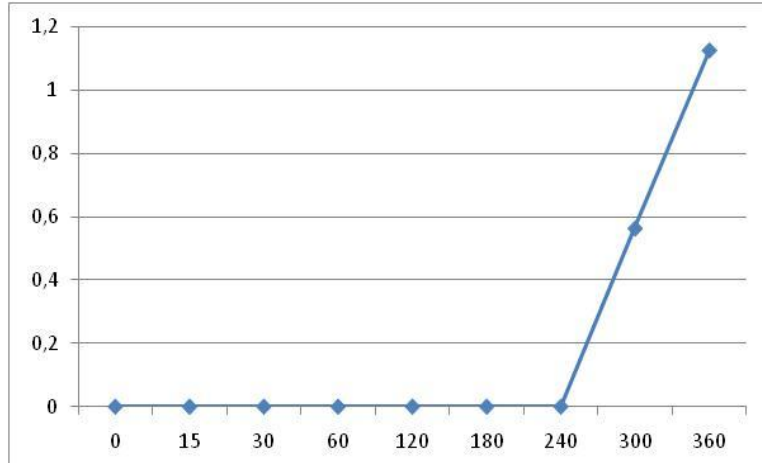

Gambar 2. Jumlah E.coli menurut Waktu Pemaparan (menit)

3. Pengaruh Intensitas Sinar UV vis Terhadap Kualitas Mikrobiologi Air Minum

Pengaruh intensitas sinar UV vis terhadap jumlah bakteri Coliform dan E.coli pada air minum dinilai menggunakan uji Regresi Linier. Hasil analisis statistik adalah berikut.

Tabel 5. Pengaruh Intensitas Sinar UV vis terhadap Jumlah Coliform dan E.coli

\begin{tabular}{lcc}
\hline & Coliform & E.Coli \\
\hline $\mathrm{R}^{2}$ & 0,015 & 0,001 \\
$\mathrm{~F}$ & 1,857 & 0.095 \\
$\mathrm{p}$-value (F) & 0,175 & 0,758 \\
Beta & $-0,121$ & $-0,028$ \\
p-value (Beta) & 0,175 & 0,758 \\
\hline
\end{tabular}

Hasil analisis menunjukkan tidak terdapatnya hubungan linier antara intensitas sinar UV vis terhadap jumlah bakteri Coliform $(p$-value $=0,175)$ dan E.coli $(p$-value $=0,758)$.

4. Pengaruh Waktu Pemaparan dan Intensitas Sinar UV vis Terhadap Kualitas Mikrobiologi Air Minum

Analisis menggunakan teknik regresi linier dengan model trimming, yaitu melakukan analisis regresi linier secara bertahap dengan mengeluarkan variabel independen yang memiliki nilai signifikasi kurang dari 0,05 , dimulai dari variabel yang memiliki nilai signifikasi uji $\mathrm{T}$ terbesar.

Pada penelitian ini, proses analisis di lakukan dua tahap. Tahap pertama, memasukkan seluruh variabel independen ke dalam model, yaitu variabel intensitas sinar UV vis dan waktu pemaparan. Hasil analisis mendapatkan bahwa variabel intensitas sinar UV vis tidak menunjukkan hubungan yang linier terhadap bakteri Coliform $(p$-value $=0,951), \quad$ sehingga dikeluarkan dari model. Tahap kedua, dilakukan analisis dengan memasukkan variabel independen waktu pemaparan ke dalam model. Hasil analisis tahap pertama dan kedua sebagai berikut:

Tabel 5. Pengaruh Varabel Penelitian terhadap Jumlah Coliform

\begin{tabular}{|c|c|c|c|c|}
\hline \multicolumn{5}{|c|}{ Tahap Pertama } \\
\hline & abel & $\mathrm{B}$ & Beta & $p$-value \\
\hline \multirow{2}{*}{\multicolumn{2}{|c|}{ Intensitas }} & $-1,273$ & & 0,075 \\
\hline & & 0,002 & -0.005 & 0,948 \\
\hline \multicolumn{2}{|c|}{ Paparan } & 0,018 & -0.603 & 0,0001 \\
\hline $\mathrm{R}$ & $=0,602$ & \multicolumn{2}{|c|}{$\mathrm{F}$} & $=35,468$ \\
\hline $\mathrm{R}^{2}$ & $=0,362$ & \multicolumn{2}{|c|}{ p-value } & $=0,0001$ \\
\hline \multicolumn{5}{|c|}{ Tahap Kedua (Fit Model) } \\
\hline \multirow{2}{*}{\multicolumn{2}{|c|}{ Variabel }} & $\mathrm{B}$ & Beta & $p$-value \\
\hline & & $-1,237$ & & 0,005 \\
\hline \multicolumn{2}{|c|}{ Paparan } & 0,018 & 0,602 & 0,0001 \\
\hline $\mathrm{R}$ & $=0,602$ & $\mathrm{~F}$ & & $=71,497$ \\
\hline $\mathrm{R}^{2}$ & $=0,362$ & & & $=0,0001$ \\
\hline
\end{tabular}

Hasil analisis statistik menunjukkan nilai $\mathrm{F}=71,497$ dengan $p$-value $=0,0001$. Sehingga disimpulkan model di atas sudah benar dan layak 
menjelaskan hubungan antara variabel waktu pemaparan terhadap jumlah bakteri Coliform. Besarnya pengaruh variabel waktu pemaparan terhadap jumlah bakteri Coliform sebesar 59,2\%.

Pada penelitian ini juga dilakukan analisis dua tahap untuk menilai pengaruh variabel intensitas sinar UV vis dan waktu pemaparan terhadap jumlah bakteri E.coli.

Hasil analisis mendapatkan bahwa variabel intensitas sinar UV vis tidak menunjukkan hubungan yang linier terhadap bakteri Coliform ( $p$-value $=0,951)$, sehingga dikeluarkan dari model. Tahap kedua, dilakukan analisis dengan memasukkan variabel independen waktu pemaparan ke dalam model. Hasil analisis tahap pertama dan kedua disajikan pada tabel berikut. Tabel 6. $\begin{aligned} & \text { Pengaruh Varabel Penelitian } \\ & \text { terhadap Jumlah E.coli }\end{aligned}$

\begin{tabular}{|c|c|c|c|c|}
\hline \multicolumn{5}{|c|}{ Tahap Pertama } \\
\hline \multirow{2}{*}{\multicolumn{2}{|c|}{ Variabel }} & B & Beta & $p$-value \\
\hline & & $-0,269$ & & 0,408 \\
\hline \multicolumn{2}{|c|}{ Intensitas } & 0,003 & 0,232 & 0,010 \\
\hline \multicolumn{2}{|c|}{ Paparan } & 0,003 & 0,021 & 0,816 \\
\hline $\mathrm{R}$ & $=0,229$ & $\mathrm{~F}$ & \multicolumn{2}{|c|}{$=3,346$} \\
\hline $\mathrm{R}^{2}$ & $=0,052$ & p-value & \multicolumn{2}{|c|}{$=0,035$} \\
\hline \multicolumn{5}{|c|}{ Tahap Kedua (Fit Model) } \\
\hline \multicolumn{2}{|c|}{ Variabel } & $\mathrm{B}$ & Beta & $p$-value \\
\hline \multirow{2}{*}{\multicolumn{2}{|c|}{ Paparan }} & $-0,209$ & & 0,295 \\
\hline & & & 0,228 & 0,010 \\
\hline $\mathrm{R}$ & $=0,229$ & $\mathrm{~F}$ & \multicolumn{2}{|c|}{$=0.689$} \\
\hline $\mathrm{R}^{2}$ & $=0,052$ & p-value & \multicolumn{2}{|c|}{$=0,010$} \\
\hline
\end{tabular}

Hasil analisis statistik menunjukkan nilai $\mathrm{F}$ $=0,689$ dengan $p$-value $=0,010$. Sehingga dapat disimpulkan bahwa model di atas sudah benar dan layak menjelaskan hubungan antara variabel waktu pemaparan terhadap jumlah bakteri E.coli. Besarnya pengaruh variabel waktu pemaparan terhadap jumlah bakteri E.coli sebesar 22,8\%.

\section{PEMBAHASAN}

\section{Kualitas Mikrobiologi Air Minum}

Hasil penelitian mendapatkan bahwa rerata jumlah Coliform sebelum perlakukan sebanyak 0,00/100ml, sedangkan sesudah perlakukan $1,72 / 100 \mathrm{ml}(\mathrm{SD}=3,64 / 100 \mathrm{ml})$. Jumlah E.coli sebelum perlakuan sebanyak $0,00 / 100 \mathrm{ml}$, sedangkan rerata sesudah perlakukan sebanyak 0,21/100 $\mathrm{ml}(\mathrm{SD}=1,36 / 100 \mathrm{ml})$.

Mengacu kepada persyaratan mikrobiologi air minum (Kemenkes RI, 2010), sebelum diberikan perlakuan, seluruh sampel air minum yang digunakan pada penelitian telah memenuhi persyaratan kesehatan $(0,00 / 100 \mathrm{ml})$. Namun setelah diberikan perlakuan, yaitu paparan sinar UV vis, maka sebanyak 24,2\% sampel air minum menjadi tidak memenuhi persyaratan jumlah bakteri Coliform pada air minum. Sedangkan yang tidak memenuhi persyaratan jumlah bakteri E.coli sebanyak 2,3\%. Menurut Kemenkes RI (2010), kualitas mikrobiologi air minum mensyaratkan tidak boleh ditemukannya bakteri Coliform dan E.coli.

Pada penelitian ini juga dilakukan uji statistik menggunakan uji $\mathrm{T}$ dependent untuk mengetahui perbedaan jumlah Coliform dan E.coli sebelum dan sesudah perlakuan. Hasil analisis statistik menunjukkan adanya perbedaan yang signifikans jumlah Coliform antara sebelum dan sesudah perlakukan ( $p$-value $=0,0001)$. Sedangkan pada E.coli, belum menunjukkan perbedaan yang signifikans ( $p$-value $=0,083)$. Dari hasil ini dapat disimpulkan bahwa proses fotoreaktivasi dapat terjadi pada air minum isi ulang setelah mendapatkan paparan sinar matahari tidak langsung.

Bakteri Coliform merupakan salah satu mikroorganisme patogen dalam air yang dapat masuk ke dalam tubuh dengan perantaraan air minum atau infeksi pada luka yang terbuka. Mikroorganisme ini umumnya tumbuh dengan baik di dalam saluran pencernaan keluar bersama feses (Tarigan, 1988). Adanya hubungan antara tinja dengan Coliform, maka bakteri ini dijadikan indikator alami kehadiran materi fekal. Sehingga, jika pada suatu substrat atau benda didapatkan bakteri ini maka langsung ataupun tidak langsung substrat atau benda tersebut sudah dicemari oleh materi fekal. Kehadiran bakteri Coliform dalam jumlah tertentu di dalam substrat ataupun benda, misalnya air dan bahan makanan, juga merupakan indikator kehadiran bakteri penyakit lainnya.

Pada pengolahan air minum isi ulang, proses pengolahan air minum yang dilakukan di depot air minum melalui dua tahap, yaitu penyaringan dan desinfeksi (Deperindag RI, 2004). Penyaringan bertujuan untuk menurunkan kandungan fisik pada air, sedangkan desinfeksi bertujuan untuk meniadakan mikroba patogen, antara lain bakteri Coliform. Menurut Suprihatin (2003), terdapat tiga metode yang sering digunakan pada proses desinfeksi air minum, yaitu metode sinar ultraviolet (UV), ozonisasi dan reversed osmosis. Metode ultraviolet merupakan metode yang paling banyak digunakan karena mudah, murah, tanpa residu, dan mampu membunuh semua jenis mikroba. 
Mekanisme aksi pada proses desinfeksi menggunakan sinar UV adalah dengan cara merusak DNA pada inti sel. Sinar UV yang digunakan untuk proses desinfeksi adalah sinar UV tak tampak dengan panjang gelombang 100$400 \mathrm{~nm}$. Namun, bakteri memiliki kemampuan seluler untuk memperbaiki bagian DNA yang rusak dengan tujuan meminimalisir instabilitas genetik. Kemampuan ini disebut DNA Repair.

Menurut Kusnadi (2013), DNA repair merupakan suatu mekanisme perbaikan DNA yang mengalami kerusakan atau kesalahan yang diakibatkan oleh proses metabolisme yang tidak normal, radiasi dengan sinar UV, radiasi ion, radiasi dengan bahan kimia, atau karena adanya kesalahan dalam replikasi. Menurut Said, NI (2007), fotoreaktivasi dapat terjadi pada mikroba yang telah terpapar UV oleh gelombang cahaya tampak (visible) antara $300 \mathrm{~nm}$ dan $500 \mathrm{~nm}$. Sedangkan Kusnadi, dkk, (2013) menyebutkan bahwa proses fotoreaktivasi terjadi karena dibantu oleh cahaya yang kelihatan dalam rentang 320-370 nm.

Perbaikan DNA akibat kerusakan oleh sinar UV dapat dikelompokkan menjadi :

1. Demage Reversal, yaitu penggantian secara langsung. Merupakan cara perbaikan DNA dengan melibatkan pembuangan atau pembalikan DNA yang rusak oleh sebuah enzim tunggal yang tergantung oleh cahaya. Pada bakteri E. Coli enzim itu dikodekan oleh gen $p h r$. Adanya kerusakan pada suatu segmen pirimidin (timin dan sitosin) yang telah berpasangan (dimer) pada suatu struktur DNA, akan mengaktifkan suatu proses perbaikan dimana suatu kompleks protein enzim fotoreaktif akan memutuskan ikatan hydrogen tetapi tanpa memutus ikatan fosfodiester antar nukleotida. Perubahan urutan akan diperbaiki dengan pergantian sesame nukleotida dengan basa pirimidin, dan akan diikuti proses penangkupan kembali celah yang semula tercipta.

2. Demage Removal. Proses ini lebih kompleks karena melibatkan replacing atau penggantian dengan dipotong-potong. Terdapat tiga metode repair DNA pada kelompok ini:

a. Base excision repair, hanya 1 basa yang rusak dan digantikan dengan yang lain.

Tempat kerusakan basa tersebut dinamakan dengan "Abasic site" atau "AP site". Pada E.coli enzim DNA glycosilase dapat mengenal AP site dan membuang basanya. Kemudian AP endonuklease membuang AP site dan Nukleotida sekitarnya. Kekosongan akan diisi dengan bantuan DNA Polymerase I dan DNA Ligase. DNA polymerase I berperan didalam mensintesis atau menambahkan pasangan basa yang sesuai dengan pasangannya.sedangkan DNA Ligase berperan dalam menyambungkan pasangan basa yang telah disintesis oleh DNA polymerase I.

b. Nucleotide excision repair, adalah memotong pada bagian/salah satu segmen DNA, dari DNA yang mengalami kerusakan. Kerusakan nukleotida yang disebabkan oleh sinar UV, sehingga terjadi kesalahan pirimidin dimer (kesalahan dua basa tetangga). Pada E. Coli terdapat protein yang terlibat dalam proses pembuangan atau pemotongan DNA yang mengalami kerusakan, protein tersebut adalah UVrA, $\mathrm{UVrB}, \mathrm{UVrC}$, setelah protein tersebut mengenali kesalahan, maka nukleotida yang rusak tersebut dihilangkan (dipotong) sehingga terjadi kekosongan pada segmen untaian nukleotida tersebut. Selanjutnya untuk mengisi kekosongan tersebut maka RNA polymerase I mensintesis nukleotida yang baru untuk dipasangkan pada segmen DNA yang mengalami kekosongan tadi, tentu saja dengan bekerjasama dengan DNA ligase dalam proses penyambungan segmen DNA tersebut.

c. Mismatch repair. Pada tahap ini yaitu memperbaiki kesalahan-kesalahan yang terjadi ketika DNA disalin. Selama replikasi DNA, DNA polymerase sendirilah yang melakukan perbaikan salah pasang. Polimerase ini mengoreksi setiap nukleotida terhadap cetakannya begitu nukleotida ditambahkan pada untaian. Dalam rangka mencari nukleotida yang pasangannya tidak benar, polymerase memindahkan nukleotida tersebut kemudian melanjutkan kembali sintesis. Proteinprotein lain selain DNA polymerase juga melakukan perbaikan salah pasang

Dari uraian di atas maka penggunaan sinar UV dengan panjang gelombang 100-300 nm untuk proses desinfeksi air minum isi ulang masih memberikan risiko terjadinya fotoreaktivitas, yaitu kemampuan memperbaiki DNA akibat paparan sinar UV dengan panjang golombang 300-500 $\mathrm{nm}$. Untuk menghilangkan risiko tersebut, maka upaya yang dapat dilakukan antara lain :

a. Menghindari paparan sinar matahari tak langsung sebagai sumber sinar UV vis pada 
air minum isi ulang. Paparan sinar UV vis dilakukan dengan cara menutup galon air dengan bahan tidak tembus cahaya.

b. Melakukan kombinasi proses desinfeksi sinar UV dengan penggunaan ozon. Menurut Said, NI (2007), ozon dapat digunakan sebagai desinfektan karena cepat membunuh virus, bakteri dan jamur serta mikroorganisme lainnya.Dibanding senyawa khlor, ozon mempunyai kelebihan, yaitu tidak menimbulkan bau dan membuat air menjadi lebih segar.

c. Menghindari sistim stok air minum pada depot air minum. Sistim stok memungkinkan terpaparnya air minum oleh sinar matahari.

d. Dinas Kesehatan Kota/Kabupaten/ Puskesmas melakukan pengawasan dan pembinaan depot air minum.

\section{Waktu Pemaparan}

Waktu pemaparan sinar UV vis adalah lamanya waktu pemaparan atau waktu kontak sinar UV vis tidak langsung terhadap sampel air minum yang diukur menggunakan stopwatch dan dinyatakan dalam satuan menit. Waktu pemaparan ditentukan menjadi delapan, yaitu 15 menit, 30 menit, 60 menit, 120 menit, 180 menit, 240 menit, 300 menit, dan 360 menit.

Hasil penelitian menunjukkan adanya perbedaan rerata jumlah Coliform berdasarkan waktu pemaparan ( $p$-value $=0,0001) . \quad \mathrm{Uji}$ Bonferroni menunjukkan perbedaan terjadi pada menit ke-300 dan menit ke-360 setelah pemaparan sinar UV vis. Berdasarkan grafik trend, peningkatan jumlah bakteri Coliform dimulai setelah 180 menit pemaparan sinar UV vis. Hasil ini sesuai hipotesis yang dikembangkan yaitu semakin lama waktu pemaparan sinar UV vis, maka semakin tinggi jumlah Coliform pada air minum.

Pada penelitian ini juga dilakukan analisis peningkatan jumlah bakteri E.coli berdasarkan waktu paparan. Hasil analisis tidak menunjukkan adanya perbedaan jumlah bakteri E.coli berdasarkan waktu paparan $(p=0,159)$. Namun berdasarkan grafik tren, telah terjadi peningkatan jumlah bakteri E.coli mulai menit ke-300. Hasil ini sesuai hipotesis yang dikembangkan yaitu semakin lama waktu pemaparan sinar UV vis, maka semakin tinggi jumlah bakteri E.coli pada air minum.

Untuk mengetahui besarnya pengaruh waktu paparan terhadap jumlah Coliform dan E.coli dilakukan analisis regresi. Hasil analisis mendapatkan bahwa besarnya pengaruh waktu paparan terhadap jumlah Coliform sebesar
$60,2 \%$. Sedangkan pengaruh waktu paparan terhadap jumlah E.coli sebesar 22,8\%.

Hasil penelitian ini sesuai dengan Mariah R. Erlick (2005) yang menyebutkan adanya pertumbuhan bakteri E.coli pada media agar setelah mendapatkan paparan sinar UV vis. Sedangkan yang tidak dipaparkan, tidak mengalami pertumbuhan.

DM. Djurdjevic-Miloservic, et al (2011) menyebutkan adanya peningkatan jumlah bakteri E.coli setelah dipaparkan sinar UVvis sebesar 2,4 $\mathrm{J} / \mathrm{cm}^{2} /$ menit selama 20 menit. Sedangkan Nasim Abedi-Moghaddam, et al (2004) menyampaikan bahwa peningkatan bakteri E.coli terjadi setelah pemaparan sinar UV vis selama 6,5 jam.

Lamanya waktu paparan berkaitan dengan proses recovery atau perbaikan DNA. Berdasarkan hasil penelitian sebelumnya, waktu paparan sinar UV vis bergantung pada intensitas sinar UV vis yang dipaparkan. Pada penelitian DM. Djurdjevic-Miloservic, et al (2011), peningkatan jumlah bakteri E.coli setelah dipaparkan sinar UVvis selama 20 menit dengan intensitas $2,4 \mathrm{~J} / \mathrm{cm}^{2} /$ menit. Sedangkan pada penelitian ini, peningkatan jumlah Coliform dan E.coli stelah mendapat paparan sinar Uvvis selama 180 dan 300 menit. Perbedaan waktu paparan disebabkan oleh perbedaan intensitas sinar UV vis. Rerata paparan intensitas sinar UV vis pada percobaan sebesar $18,69 \mathrm{~mW} / \mathrm{cm}^{2}$ $\left(\mathrm{SD}=10,31 \mathrm{~mW} / \mathrm{cm}^{2}\right)$ atau $0,01869 \mathrm{~W} / \mathrm{cm}^{2} /$ menit atau $0,01869 \mathrm{~J} / \mathrm{cm}^{2} /$ menit.

Berdasarkan hal di atas, maka untuk menghindari terjadinya fotoreaktivasi pada air minum isi ulang adalah dengan cara menutup galon sejak pertama digunakan. Menutup galon berarti meniadakan paparan sinar UV vis terhadap air minum, sehingga menghilangkan peluang terjadi proses fotoreaktivasi.

\section{Intensitas Sinar UV vis}

Intensitas sinar UV vis adalah paparan sinar UV gelombang pendek yang diukur menggunakan UV Light meter dengan satuan $\mathrm{mWatt} / \mathrm{cm}^{2} /$ menit. Hasil penelitian menunjukkan bahwa rerata intensitas sinar UV vis tak langsung sebesar 18,69 mW (SD=10,31 mW).

Hasil analisis statistik menunjukkan tidak terdapatnya hubungan yang linier antara intensitas sinar UV vis terhadap jumlah bakteri Coliform ( $p$-value $=0,175)$, dengan nilai pengaruh sebesar $-0,121(-12,1 \%)$. Demikian pula pada bakteri E.coli. Hasil analisis statistik juga tidak menunjukkan hubungan yang linier antara intensitas sinar UV vis terhadap jumlah bakteri E.coli $\quad(p$-value $=0,758)$. Besarnya pengaruh 
intensitas sinar UV vis terhadap jumlah bakteri E.coli hanya sebesar $-0,028(-2,8 \%)$.

Hasil penelitian ini tidak sesuai dengan Kusnadi, dkk (2013) yang menyebutkan bahwa proses perbaikan DNA mikroba dibantu oleh cahaya yang kelihatan dalam rentang 320-370 nm. Said, NI (2007), menyebutkan bahwa fotoreaktivasi dapat terjadi pada mikroba yang telah terpapar UV oleh gelombang cahaya tampak (visible) antara $300 \mathrm{~nm}$ dan $500 \mathrm{~nm}$.

Hasil penelitian ini juga tidak sesuai dengan Mariah R. Erlick (2005), bahwa pertumbuhan bakteri E.coli pada media agar setelah mendapatkan paparan sinar UV vis. DM. Djurdjevic-Miloservic, et al (2011) menyebutkan adanya peningkatan jumlah bakteri E.coli setelah dipaparkan sinar UVvis sebesar $2,4 \mathrm{~J} / \mathrm{cm}^{2} /$ menit selama 20 menit. Sedangkan Nasim AbediMoghaddam, et al (2004) menyampaikan bahwa peningkatan bakteri E.coli terjadi setelah pemaparan sinar UV vis selama 6,5 jam.

Tidak diketahuinya pengaruh intensitas sinar UV vis terhadap peningkatan jumlah Coliform dan E.coli pada penelitian ini disebabkan rendahnya intensitas sinar UV vis selama percobaan. Rerata paparan intensitas sinar UV vis pada percobaan sebesar 18,69 $\mathrm{mW} / \mathrm{cm}^{2} /$ menit (SD $=10,31 \mathrm{~mW} / \mathrm{cm}^{2} /$ menit) atau $0,01869 \mathrm{~W} / \mathrm{cm}^{2} /$ menit atau $0,01869 \mathrm{~J} / \mathrm{cm}^{2} /$ menit. Jika dibandingkan dengan hasil penelitian DM. Djurdjevic-Miloservic, et al (2011) yang menyebutkan bahwa peningkatan jumlah bakteri E.coli setelah dipaparkan sinar UV vis sebesar $2,4 \mathrm{~J} / \mathrm{cm}^{2} /$ menit selama 20 menit, maka intensitas sinar UV vis selama percobaan hanya sebesar $0,77 \%$.

Rendahnya intensitas sinar UV vis selama percobaan karena sinar UV vis berasalal dari sinar matahari tidak langsung. Sehingga intensitasnya sangat dipengaruhi oleh faktor iklim. Rerata suhu udara selama percobaan sebesar $\quad 30,45^{\circ} \mathrm{C} \quad\left(\mathrm{SD}=1,3^{\circ} \mathrm{C}\right) \quad$ dan rerata kelembaban sebesar $61,40 \% \quad(\mathrm{SD}=3,37 \%)$. Sedangkan cuaca umumnya berawan menuju mendung.

Walaupun secara statistik hasil penelitian ini tidak menunjukkan adanya pengaruh intensitas sinar UV vis terhadap peningkatan jumlah Coliform dan E.coli, namun dari penelitian ini telah dibuktikan terjadinya peningkatan jumlah Coliform dan E.coli setelah dipaparkan sinar UV vis dengan intensitas yang sangat rendah. Lama pemaparan untuk Coliform selama 180 menit dan E.coli selama 300 menit. Sehingga dapat disimpulkan bahwa proses fotoreaktivasi pada air minum isi ulang dapat terjadi walaupun mendapatkan paparan sinar UV vis dengan intensitas yang sangat rendah, namun membutuhkan waktu yang lebih lama.

\section{SIMPULAN}

1. Rerata jumlah coliform dan E.coli sesudah perlakukan sebanyak 1,72/100 ml $(\mathrm{SD}=3,64 / 100 \mathrm{ml})$ dan $0,21 / 100 \mathrm{ml}$ ( $\mathrm{SD}=1,36 / 100 \mathrm{ml}$ ).

2. Terdapat pengaruh waktu pemaparan sinar UV vis terhadap peningkatan jumlah bakteri Coliform sebesar 60,2\% ( $p$-value $=0,0001)$. Peningkatan jumlah bakteri Coliform terjadi setelah 180 menit pemaparan sinar UV vis.

3. Tidak terdapat pengaruh waktu pemaparan sinar UV vis terhadap peningkatan jumlah bakteri E.coli ( $p$-value $=0,159)$.

4. Secara statistik, tidak terdapat pengaruh intensitas sinar UV vis terhadap jumlah bakteri Coliform $(p$-value $=0,152)$ dan bakteri E.coli ( $p$-value $=0,758)$.

5. Proses fotoreaktivasi pada air minum isi ulang dapat terjadi walaupun mendapatkan paparan sinar UV vis dengan intensitas yang sangat rendah, namun membutuhkan waktu yang lebih lama.

\section{SARAN}

Selain membeli air minum isi ulang dari depot air minum yang melakukan proses desinfeksi dengan kombinasi sinar UV dan ozon, menutup galon air minum sejak pertama digunakan agar tidak terpapar sinar UV vis dari matahari merupakan upaya yang harus dilakukan untuk menghindari proses fotoreaktivasi.

\section{DAFTAR PUSTAKA}

Deperindag. 2004. Kepmenperindag RI No.651/MPP/Kep/10/2004 Persyaratan Teknis Depot Air Minum dan Perdagangannya. Jakarta: Menperindag RI.
D.M. Djurdjevic, et al. 2011. The survival of Escherichia coli upon exposure to irradiation with non-coherent polychromatic polarized light. Veterinarni Medicina, 56, 2011. 
Kemenkes RI. 2010. Peraturan Menteri Kesehatan Republik Indonesia Nomor :492/MENKES/PER/IV/2010 tentang Persyaratan Kualitas Air Minum. Jakarta. Kusnadi, dkk. 2013. Mikrobiologi. http://file.upi.edu/Direktori FPMIPA/Jur._Pend._Biologi/ 19680501994031 Kusnadi/Buku_Comond_Text Mikrobiologi,_Kusnadi,dkk/Bab_VI_Gene
tika_Bankteri.pdf (Diakses pada 13 Januari 2016).

Said, NI. 2007. Desinfeksi Untuk Pengolahan Air Minum. Jakarta: Pusat Teknologi Lingkungan-BPP.

Suprihatin. 2003. Hasil Studi Kualitas Air Minum Depot Isi Ulang. Makalah pada Seminar Sehari Permasalahan Depot Air Minum dan Upaya Pemecahannya. Jakarta. 